\title{
Aboriginal relationships to the natural world: colonial 'protection' of human rights and the environment
}

\author{
Irene Watson \\ University of South Australia
}

Colonialism has challenged Aboriginal obligations and relationships to the natural world. This article describes the efforts of First Nations on the continent now known as Australia to maintain their authority and existences in the face of neoliberalism and colonialism, which the British initially inflicted and under which we still survive. The colonial policies of Australia denied our existence and at the same time attempted to demolish our languages and cultures, and to assimilate the consequences. This article asks the questions: what underpins state claims to the title to Aboriginal lands? Does Australia renounce terra nullius and the racist principles and beliefs which make up such a doctrine? And finally does Australia acknowledge and support all 'Peoples' as having an inherent right to self-determination, and as a component of such a right, that all 'Peoples' have a right to collectively care for their country and to benefit from a relationship to the land which sustains future generations of all Peoples? The possibility of a future for all life forms on earth lies in the responses states might deliver to these questions.

Keywords: law, authority, power, colonialism, Aboriginal knowledge

\section{INTRODUCTION}

In colonialism's 'New World', ancient Aboriginal ${ }^{1}$ relationships and obligations to the natural world were challenged by violence, monotheism and racism. Today our ancient relationships of caring for country remain challenged by the forces of colonialism, that, in their contemporary guise, are responsible for climate change and other ecocidal events occurring across the Earth. While the focus of this article is the impact of colonialism on the First Nations on the continent now known as Australia, the discussion has a broader resonance with colonized First Nations across the globe.

Aboriginal relationships and obligations to our territories are informed by Aboriginal laws, cultures and knowledge systems. For many First Nations, relationships to land are integral to kinship systems. ${ }^{2}$ The natural world is referred to as 'mother', and features of the land are often known as places of the grandfather or grandmother. Arising from relationships to land are obligations to care for country as one would care for oneself. This is a relational connection to land which is a core difference between Aboriginal relations to land and those of colonial legal systems that treat land as property and a mere commodity.

1. Aboriginal, First Nations, Indigenous and Peoples are used interchangeably across this article.

2. I Watson, Aboriginal Peoples, Colonialism and International Law: Raw Law (Routledge, Abingdon 2015), for a discussion of Aboriginal relationships to land. 
Ancient Peoples had inter-nation recognition of each other prior to colonialism, and First Nations Peoples held the centre and the capacity to determine our identities and ways of being in the world. We were sovereign and, in a true sense, self-determining peoples.

Part of colonialisms' destructive efforts was an attempt to rob First Nations of the capacity to determine how we are in the world, and thus our relationships to our territories. Our identities were sourced at an Aboriginal centre. With the advent of colonialism, our identities became re-characterized as being within the domestic jurisdiction of the colonizing state and became de-centred, thrust to the colonial periphery.

As a result First Nations Peoples were re-named. From being subjects in international law, we became its objects, and were thus perceived and treated as beings subject to the powers and laws of colonizing states. As Aboriginal Peoples our capacity to determine our relational beingness with the natural world was thwarted by another way of knowing humanity and the natural world, and became subjugated to the power and laws of the colonial states.

Aboriginal laws, which had from ancient times authorized a relational obligation to care for country continue to survive but under the duress of colonial legal systems. Ancient relationships and obligations to the natural world have been re-characterized in narratives such as the 'protection of human rights' and environmental laws, framed by colonial states. The consequence of this approach is to displace an Aboriginal centre or way of being in the world, and to centre a colonialist response to the natural world, one which is largely predicated upon a connection to land as property and commodity.

What kind of future do First Nations hold out for, when we compare the different approaches taken and imposed by colonialism? Do First Nations have a future as colonized peoples? What labour is to be done in the re-working of an Aboriginal centre along with the de-colonization of Aboriginal worlds? What tools are needed to communicate a process of de-centring colonial power and de-colonizing First Nations' territories? Does a process of 'intercultural translation' offer any assistance in unravelling colonialism's bonds?

This article considers the ongoing position of Aboriginal relations to country within the colonized space and the work that needs to be done in rethinking an Aboriginal centre. The centre, at its core, values relationships to the land drawn from First Nations' ontologies. Does the possibility of Aboriginal futures lie in re-centring First Nations' laws' authority and obligations, while at the same time ensuring the ongoing sustainability and health of our natural world?

In considering these questions I draw from my own Aboriginal centre and the lands of the Boandik and Meintangk First Nations Peoples, territories which are now known as the South-East of South Australia. Boandik and Meintangk territories had been managed and kept in a pristine state since time immemorial prior to colonisation. Now those lands are subject to the developments of the pastoral, forestry and tourism industries as well as a more recent and more damaging threat in the proposed use of unconventional gas extraction and fracking.

In accord with Aboriginal law we continue to have the authority and the responsibility to care for and ensure that our territories are kept alive and well for future generations. Under international law the state should be compelled to consult and obtain our free, prior and informed consent regarding any proposals to develop our lands. It is again important to note that from a sovereign, self-determining, First Nations' ontological perspective we would not have the authority to consent to the damage which could result from unconventional gas and fracking developments, as this could be consenting to an unlawful ecocidal act. 
The failure of the Australian state to address the sovereign position of First Nations Peoples in relation to the proposals to produce gas from our territories - or any of the other development projects planned and initiated across the continent - is an act of racial discrimination. It is among an avalanche of genocidal and ecocidal acts that colonists have perpetrated for more than two hundred years. The state denies the capacity of Aboriginal Peoples' obligations and authority to care for country, and this article includes case studies which reveal the challenges First Nations Peoples confront when carrying out our obligation to care for country.

\section{COLONIAL POWER - LAW-FULL AUTHORITY}

The state has power derived from a violent colonial foundation. It asserts that its rights are founded on law, but it is military power and violence that constitute the foundation of the colonial project 'Australia'. First Nations have law-full authority (a term used to note that Aboriginal Peoples are full of law, in contrast to colonial history and the application of terra nullius), but the state has the power to determine. A consequence of holding power is the capacity to assert that power is foundational. The colonial state of Australia determined the application of terra nullius and the myth of a continent without laws or peoples. In fact the entire continent was occupied by Aboriginal peoples full of law, authority and the obligation to care for country. Elders maintain that we have been here forever, while science claims that we have been here for at least sixty thousand years.

A number of early colonial correspondences said that the consent of First Nations should be obtained before the occupation and development of their territories by the colonial project. ${ }^{3}$ However, there is no evidence of the consent of the 'natives' being sought or of any acknowledgment of the need for consent by colonial administrators of the time. Land theft and attempted genocide on a large scale occurred across the continent and was not restricted by considerations of whether the consent of the 'native' had been given. It is important to note that consent could not be given to the theft and damage of land and the natural world, for these are acts which are against Aboriginal laws' core values and epistemologies, which centre a relational approach to land.

The urgency of our time calls for the continuity of Aboriginal laws, laws which have forever encoded our relational obligations to keep our natural worlds vital and alive. In addressing these obligations, First Nations still work to protect our lands from damage. ${ }^{4}$ In South Australia we are faced with developments including not only fracking and unconventional gas drilling, as already noted, but also the building of nuclear waste dumps on First Nations' lands. ${ }^{5}$ Across Aboriginal Australia, First

3. G Nettheim, "The Consent of the Natives": Mabo and Indigenous Political Rights' (1993) 15 Sydney Law Review 223; H McRae, G Nettheim and L Beacroft, Aboriginal Legal Issues: Commentary and Materials (Law Book Co, North Ryde 1991) 10.

4. N Pelle, 'Six Reasons to Keep Oil Out of the Great Australian Bight' (Greenpeace General, 27 June 2016) <https://www.greenpeace.org.au/blog/six-reasons-to-keep-oil-out-of-thegreat-australian-bight/> accessed 27 January 2018.

5. The Commonwealth Government of Australia has proposed creating a nuclear waste dump in an area which borders the Yappala Indigenous Protected area without the consultation of the Adnyamathanha people. J Norman, 'Nuclear Dump: Barndioota Station in SA Earmarked as Site of Waste Facility' (ABC News, 29 April 2016) <http://www.abc.net.au/news/2016-0429/nuclear-waste-dump-expected-south-australian-cattle-station/7369346> accessed 27 January 2018. While this proposal was advised against in 2017 by a citizens' tribunal and an 
Nations are standing with our ancient laws and obligations to ensure our territories remain alive and well for future generations.

\section{INTER-NATIONS AND INTERNATIONAL LAWS}

With international law being an artefact of colonialism, ${ }^{6}$ what are the possibilities for First Nations' laws continuing to be maintained and for international laws' capacity to provide a reprieve from the dichotomy of the two worlds we live in?

Across ancient Aboriginal (Australian) history there was a body of 'treaty' agreements amongst and between First Nations Peoples. However, there are, as yet, no treaties between the First Nations Peoples and the colonizers. The doctrine of terra nullius ${ }^{7}$ was used as an excuse to annihilate Indigenous Peoples, and the position has not been altered post-Mabo ${ }^{8}$ and the Native Title legislation. ${ }^{9}$ If anything, these latter-day laws have entrenched the colonizers' position and quest for legitimacy. ${ }^{10}$ From a First Nations' sovereign position we confront a process of retrogression; we are being deprived of the essential attributes of our identity as sovereign subjects in international law piece by piece. While our original status as sovereign nations was grounded in our territory, now our capacity to enter into international agreements and govern ourselves is being undermined by relentless assimilationist policies of the state. ${ }^{11}$ Nevertheless, Aboriginal law cannot be assimilated or extinguished, for there is no principle within Aboriginal jurisprudence which enables extinguishment. The logic that our law could be extinguished would assume that as Aboriginal Peoples we have consented to our own genocide and/or juridicide, an idea which goes against reason, morality and law.

The status and participation of First Nations Peoples in international fora provide further evidence of the ongoing racism of colonialist doctrines such as terra nullius, as well as the power of the colonial states to continue to name who First Nations are and what status is to be accorded them. These concerns were raised in the 1999 UN Treaty Study Report, ${ }^{12}$ in which the then Special Rapporteur, Miguel Martínez, recommended that opportunities be made available for Indigenous Peoples to speak as true subjects of international law in the voice of their own peoples, rather than being spoken for by larger, representative NGO bodies. ${ }^{13}$ However, this recommendation was not taken up, and the ongoing exclusion of Indigenous Peoples as sovereign subjects of international law, based upon racist ideologies, is determined by the ongoing

overwhelming vote against any nuclear dump being sited in SA, the new Liberal government, incoming at March 2018 has re-set the agenda and opened the state to considering a nuclear waste dump once again.

6. A Anghie, Imperialism, Sovereignty and the Making of International Law (Cambridge University Press, Cambridge 2008).

7. The idea of the land being empty of peoples, laws and governance.

8. Mabo v Queensland (No 2) (1992) 175 CLR 1.

9. Native Title Act 1993 (Cth).

10. Final report by Miguel Alfonso Martínez, Special Rapporteur: Study on Treaties, Agreements and other Constructive Arrangements between States and Indigenous Populations, E/CN4/Sub2/1999, para 100.

11. Ibid para 105.

12. Ibid para 47.

13. See Sharon Venne, Our Elders Understand Our Rights: Evolving International Law Regarding Indigenous Peoples (Theytus Books, Penticton 1998). 
de-jure power held by states ${ }^{14}$ to determine and construct whom and what are 'proper' sovereign subjects of international law. ${ }^{15}$

First Nations' laws have always been here. Our laws are in the land and are carried in the lives of Aboriginal people. Aboriginal laws remain living in the land, and the obligations held by First Nations to care for the natural world are ongoing. Our connections to ruwi - our land - date from the beginning of time, and those ancient connections have been sung ${ }^{16}$ by hundreds of generations of Aboriginal Nations. Our Nations' ontological worldviews differed from those of the British Empire and remain different from its successor, the Australian State. Aboriginal relationships to the natural world are different from those recognized by the Australian state, which translates them as 'property'. As sovereign peoples, from ancient times, we have acknowledged the boundaries of our sovereign Aboriginal nations. We have always respected them. For thousands of years our song lines have determined the First Nations' boundaries of Aboriginal Australia, ${ }^{17}$ and we have retained law-full relations between our nations

14. Study on Treaties, above (n 10), paras 50 and 55.

15. The United Nations working definition of 'Indigenous Peoples' was developed by the Special Rapporteur of the Sub-Commission on Prevention of Discrimination and Protection of Minorities, Martínez Cobo, in his 1986 report on the 'Study of the Problem of Discrimination Against Indigenous Populations', Cobo Report UN Doc E/CN4/Sub2/1986/7 and Add. 1-4 as follows:

Indigenous communities, Peoples and nations are those which, having a historical continuity with pre-invasion and pre-colonial societies that developed on our territories, consider themselves distinct from other sectors of the societies now prevailing on those territories, or parts of them. They form at present non-dominant sectors of society and are determined to preserve, develop and transmit to future generations our ancestral territories, and our ethnic identity, as the basis of our continued existence as Peoples, in accordance with our own cultural patterns, social institutions and legal system.

This historical continuity may consist of the continuation, for an extended period reaching into the present of one or more of the following factors:

a) Occupation of ancestral lands, or at least of part of them;

b) Common ancestry with the original occupants of these lands;

c) Culture in general, or in specific manifestations (such as religion, living under a tribal system, membership of an Indigenous community, dress, means of livelihood, lifestyle, etc.);

d) Language (whether used as the only language, as mother-tongue, as the habitual means of communication at home or in the family, or as the main, preferred, habitual, general or normal language);

e) Residence on certain parts of the country, or in certain regions of the world;

f) Other relevant factors.

On an individual basis, an Indigenous person is one who belongs to these Indigenous populations through self-identification as Indigenous (group consciousness) and is recognized and accepted by these populations as one of its members (acceptance by the group). This preserves for these communities the sovereign right and power to decide who belongs to them, without external interference.

16. Aboriginal Nations of Australia refer to our laws as songs that live in the land, for they have been sung from the beginning of time. Our songs are a narrative for a good way to live and the responsibilities that are attached to living a good life.

17. See Watson, above (n 2), for an introduction to song laws across Aboriginal Australia. 
for as long. Such respect and reciprocity was, and is, in the first laws of the continent now named Australia; they are the first evidence of inter-nation relationships.

Pre-colonial Aboriginal Australia is an example of the earliest known international relations, and evidence of those relationships can be identified in the density of those relationships. There were more than 500 Aboriginal languages spoken across the continent we now call Australia and many of those languages have survived and are being revitalized today. Aboriginal First Nations have always been subjects of international law and demonstrated lawful relationships and protocols of engagement between nations. ${ }^{18}$ These international relationships are ancient and pre-existed, by thousands of years, the emergence of colonialism and its framing of latter-day international law. ${ }^{19}$ As subjects of international law, First Nations indeed have the authority to be self-determining in how we relate to and care for our territories. The denial of our existence as nations of Peoples over more than two-hundred and thirty years of colonisation is ongoing and is legitimized only by colonial violence and by acts of racial supremacy. ${ }^{20}$

\section{ABORIGINAL WAYS OF BEING: OBLIGATIONS AND RELATIONSHIPS}

First Nations' relationships with the land makes us one with the natural world. Our lands and our natural world provide sustenance, enabling us to live and to develop our nations. Our 'sung' lands have defined our respective cultures, identities and existences as 'Aboriginal Peoples'. With colonization there came another law and another way of knowing law; this law denied our existence while silencing and burying our ontologies and epistemologies.

Aboriginal inherent rights are based upon our respective nations' time-immemorial presence and connections to our lands, and laws given us in relation to our lands by Kaldowinyeri, ${ }^{21}$ since the beginning of time. Our presence, connection and received laws created an unbreakable responsibility to and relationship with our lands which predates British common law conceptions of real property and the common law of Australia by thousands of years. We have never relinquished, ceded or surrendered responsibility or ownership, as such extinguishment and associated actions are not possible within our ontology, worldview or laws.

The Australian state has consistently imposed its laws, policies and procedures on our Nations and lands by force, based on the false and racist premise that our inherent rights to our lands and natural world are subservient to the Australian Crown's 'presumed underlying title' to them. The belief in the Crown's presumed underlying title is based on racially offensive colonial ideologies and attitudes which were, and remain, enshrined in the doctrine of terra nullius.

18. N Tindale, 'Aboriginal Tribal Boundaries', <http://archives.samuseum.sa.gov.au/tribalmap/> last accessed 28 March 2018; for a discussion of the complexity and density of Aboriginal relationships to land, B Pascoe, Dark Emu, Black Seeds: Agriculture or Accident? (Magabala Books, Broome 2014).

19. Anghie, above (n 6).

20. L Ryan, 'Settler Massacres on the Port Phillip Frontier, 1836-1851' (2010) 34 Journal of Australian Studies 257; H Reynolds, The Question of Genocide in Australia's History: An Indelible Stain? (Penguin, Ringwood 2001).

21. Kaldowinyeri means the law in the language of the Tanganekald Peoples, but also the way of life, and the living of a good life; a life which is lawful. There are hundreds of First Nations languages and all of them have an equivalent word. 
Kombu-Merri and Waka Waka philosopher, Mary Graham, argues that First Nations have managed this country forever and that we still have the authority to do so today. She argues that the source for that authority is the land:

The two most important kinds of relationship in life are, firstly, those between land and people and, secondly, those amongst people themselves, the second being always contingent upon the first. The land, and how we treat it, is what determines our human-ness. Because land is sacred and must be looked after, the relation between people and land becomes the template for society and social relations. Therefore, all meaning comes from land. ${ }^{22}$

While colonial 'law' denies Aboriginal Peoples the power to determine what happens to the land in relation to most colonial projects, Aboriginal Peoples continue to hold the lawful authority to carry out ancient obligations to care for country. Many First Nations share the obligation to care for country; it is in our laws to ensure that future generations, not only human but those of all species, including our ngaitji ${ }^{23}$ relations, have a sustainable future. To continue current global trends of 'progress and development' is to ensure the decline of all life on earth and the extinction of many more species.

Aboriginal Peoples do not have a mandate to consent to the destruction of the natural world. The UN Declaration on the Rights of Indigenous Peoples, although only international soft law, recognizes that states have an obligation to consult with and obtain the free, prior and informed consent of Aboriginal Peoples regarding any proposals to develop Aboriginal lands. ${ }^{24}$ However from a First Nations' ontological standpoint, we could not consent to the destruction of our territories, because we know, without the land we are without food and water, and the future of humanity, along with other species, is threatened.

\section{NATURAL WORLD, RE-BRANDED AS PROPERTY}

The myth of terra nullius continues to underpin Australian law and the denial of Aboriginal Peoples as subjects in international law. ${ }^{25}$ This remains the case even though terra nullius was in part rejected in Mabo (No 2), ${ }^{26}$ for the purpose of 'recognizing' Aboriginal title. ${ }^{27}$ The High Court of Australia in Mabo (No 2$)^{28}$ determined a limited recognition of First Nations' relationships to land, while not unsettling the 'skeletal' principle of colonial law. It decided that to reject terra nullius entirely

22. M Graham, 'Some Thoughts about the Philosophical Underpinnings of Aboriginal World Views' (2008) 45 Australian Humanities Review 181, 181-2 <http://www.australianhumaniti esreview.org/archive/Issue-November-2008/graham.html> accessed 27 January 2018.

23. Our ngaitji represents the relationship or kinship we share with our surrounding natural world. The ngaitje is a relationship which teaches us about the unity we share with all life forms of the natural world.

24. United Nations Declaration on the Rights of Indigenous Peoples, UNGA Res 61/68, UN Doc A/RES/61/295 (13 September 2007) (hereinafter the Declaration), Art 32(2) outlines the minimum standard regarding negotiations with Indigenous Peoples.

25. Mabo v Queensland (No 2) (1992) 175 CLR 16 (Brennan J) (High Court of Australia); Watson, above (n 2).

26. Mabo v Queensland (No 2) (1992) 175 CLR 69 (Brennan J) (High Court of Australia).

27. Watson, above (n 2), 88-9.

28. Mabo v Queensland (1992) 175 CLR 1, 16 (Brennan J) (High Court of Australia). 
would be to pull the foundation of the colonial state from under itself, and destabilize its existence. ${ }^{29}$

The recognition by Australian law of an Aboriginal title or a native title 30 'right' does not enable Aboriginal obligations to care for country, beyond the 'right' to negotiate with the state and private lease and licence holders regarding developments impacting native title lands. There is no power of veto over potential and damaging land developments that treat the natural world as a resource for appropriation and economic growth, and for the 'development of the state'. ${ }^{31}$ Colonial law deems accumulation a natural activity of all human societies and the premise of the natural-resource industries. The colonial process of framing the natural world as property, that it is divided up for sale, profit and exploitation, is an unacknowledged breach of our laws, as if Aboriginal laws do not exist. Thus, while Mabo (No 2) was hailed for rejecting terra nullius, ${ }^{32}$ in practice the decision upheld it, while at the same time appearing virtuous for its claim that it was responsible for its demise.

The challenge remains for non-Indigenous people to see First Nations from another horizon, namely a horizon of law which exists outside of and beyond terra nullius and the colonial matrix. This requires a shift away from seeing virtue in the commodification of land and away from constructions of Aboriginality as backward savagery without law. We need to look through a lens that can see a First Nations standpoint.

We have always been here. Despite our lands being construed as 'property' by the colonial legal system, First Nations continue to maintain a lawful relational connection to the land and our natural world which exceeds the 'property' paradigm. We have never ceded our sovereignty and never consented to a terra nullius construct of our nations. The assumption that the colonizers could subjugate us to their way of being and dismantle our relationships to our laws and our lands, is a denial of our ways of existence. It is an act of racism, which continues to occur in commonwealth and state jurisdictions and political policy across Australia. ${ }^{33}$

29. Ibid 30, a position which has become entrenched and further limited by the Native Title Act 1993 (Cth); For further discussion, see Watson, above (n 2), 30-31, 88-9, 130-2, 156.

30. The Native Title Act 1993 was enacted following the decision in Mabo. While recognizing Aboriginal title the NTA validated non-Aboriginal title which was at risk of becoming invalidated due to the Racial Discrimination Act 1975 (Cth). The Native Title Act 1993 limited the already limited 'recognition' of Aboriginal title established in Mabo, affirming that the Crown retained exclusive title to all lands subject to an Aboriginal title, and that Aboriginal title could be extinguished by the Crown. Aboriginal title is only a beneficial right to use land, and is thus one of the most marginal forms of property rights recognition within Australian property law. Aboriginal title does not recognize or enable a relational and caring-for-country responsibility. 31. See R Merino, 'The Politics of Extractive Governance: Indigenous Peoples and SocioEnvironmental Conflicts' (2015) 2 The Extractive Industries and Society 85, for a discussion of the impact of resource development on Indigenous Peoples in Bolivia.

32. The common-law position prior to Mabo was the 1971 case Millirrpum v Nabalco Pty Ltd: '... On the foundation of New South Wales ... every square inch of territory in the colony became the property of the Crown. All titles, rights, and interests whatever in land which existed thereafter in subjects of the Crown were the direct consequence of some grant from the Crown. The plaintiffs, who cannot point to any grant from the Crown as the basis of the title which they claim, cannot succeed ...'. More than twenty years later Mabo v Queensland (No 2) (1992) 175 CLR 1 overturned Millirrpum when it 'recognized' an Aboriginal title to land.

33. For a further discussion, see I Watson, 'Sovereign Spaces, Caring for Country and the Homeless Position of Aboriginal Peoples' (2009) 108 South Atlantic Quarterly 27. 
The machine of terra nullius was fitted with Eurocentric paradigms of 'progress', whereby the British assumption of title to Aboriginal lands was sanctioned by various ideologies, namely that Aboriginal peoples were 'backward' and 'uncivilized', did not wear clothes or till the soil, and therefore were unfit to 'own' land. The progress paradigm provided the legitimacy for the foundation of Australia, where the Crown's underlying absolute or radical title to Aboriginal lands is assumed. The ancient relationships that hundreds of First Nations' had to land simply became 'Crown title'. In reality, on the ground it was not that simple; warfare was continuous along the frontier, and the massacre of peoples, likewise continuous. Inside the frontier, repressions continue to this day.

Prior to the colonial invasion of our lands, our old people called themselves by our ancient First Nations language names; our songs and stories still lie in the land, and with them remains the ownership of country held by sovereign Indigenous Peoples. This is a form of ownership which cannot be extinguished by the laying-over of a colonial paper title, nor by the latterly-constructed 'native title' process (which remains in Australian law, inferior to the colonial 'freehold'). We are excluded from the right to hold and own land unless we buy it back from the colonists, but we are also denied more broadly the right to have an Indigenous worldview held in a distinct body of Indigenous Knowledges. ${ }^{34}$

The 'recognition' of an Aboriginal title is akin to the game of giving with one hand and taking with the other. The 'recognition' of native title has attracted controversy amongst both Aboriginal and non-Aboriginal peoples. Aboriginal critics claim that native title is not about the recognition of land rights, ${ }^{35}$ while non-Aboriginal interests, comprising powerful industry groups, complain that Aboriginal title claims place the backyards of 'Aussies' under threat. ${ }^{36}$ How real is the imagined threat? The reality is that non-Aboriginal property rights are well secured and not threatened by Mabo; Brennan J made this quite clear, his judgment ensuring that the 'skeletal foundation' of the Australian state remains intact and undisturbed by the recognition of Aboriginal title. ${ }^{37}$ But the key problem is that Aboriginal native title has been represented as something it was never intended to be, and never could be, that is, land rights and self-determination for First Nations Peoples. Our relationships to land and obligations to care for country are not enabled by Aboriginal title. ${ }^{38}$

\section{ABORIGINALITY - COLONIAL IDENTITES?}

The principle of terra nullius empowered the Crown to hold full title over First Nations' territories and to determine every aspect of Aboriginal identity. The new

34. Study on Treaties, above (n 10), para 223.

35. See Mabo v Queensland (n 28).

36. Australian Mining Industry Council, Advertisement, The Age (Melbourne, 14 August 1993); The Weekend Australian (Sydney, 21-2 August 1993).

37. In Mabo (No 2) (1992) 175 CLR 1, 30 (High Court of Australia), the fragility of the Australian legal foundation is discussed by Brennan $\mathrm{J}$.

38. Irene Watson discusses the capacity for Australian environmental laws to care for country. See I Watson, 'Aboriginal Laws of the Land: Surviving Fracking, Golf Courses and Drains among other Extractive Industries' in N Rogers and M Maloney (eds), Law as if the Earth Really Mattered: The Wild Law Judgment Project (Routledge, Abingdon 2017) 209-18. Under the South Australian Aboriginal Heritage Act 1988, s 23, power is held by the Minister to authorize the destruction of Aboriginal sites. Under s 23, the authority of the Minister is required before 'damaging, disturbing or interfering with' Aboriginal sites. 
Australian colonies each enacted their own Aborigines Acts and ordinances, ${ }^{39}$ which positioned Crown power over Aboriginal First Nations' authority. First Nations survivors of frontier massacres were rounded up and removed from their traditional territories, often relocated hundreds of kilometres away, and detained in concentration camps known as Aboriginal reserves or Christian missions. ${ }^{40}$ Life under the Aborigines Acts offered two options: to await death or absorption into the whiteness of the colonial project.

The Aborigines Acts controlled the movement of Aboriginal peoples across our territories, which were systematically invaded by pastoralists and farmers. Aboriginal reserves provided enclaves of slave labour for the local pastoral and agricultural industries at a time when slavery was supposedly no longer practised within the boundaries of British 'law'. For their work, Aboriginal people received bare survival rations. As the pastoral holdings, towns and settlements expanded, more Aboriginal detention centres or 'reserves' were set aside, usually outside town boundaries. The survivors of the initial assaults of the invasion were removed to them - and thereby rendered invisible. Aboriginal lives were determined by a system of permits: permission to leave the reserve, permission to return, permission to marry, etc. Ownership of land was impossible. One class of permits provided for 'exemption' from the Aborigines Acts. The exemption system was designed to assimilate Aboriginal peoples into white Australia, separating families and communities. Movement away from a detention centre was sometimes permitted based on the consideration of a quantum of 'white' and 'black' blood and the 'perceived intelligence' of the individual. ${ }^{41}$

Exemption from the provisions of the Aborigines Act did not imply freedom from the Act; the Aborigines Protection Board could revoke the exemption at any time. Certificates of exemption were issued without notice and given to individuals without their consent. ${ }^{42}$ Indeed, the exemption permits were sometimes used as a punitive measure to expel Aboriginal people from reserves, and once expelled, they were restricted from further contact with their family. Families or individuals wanting to return to the mission were forced to apply for a permit, which was frequently refused. ${ }^{43}$ The process was effective in disrupting relationships to land and kin and in particular the capacity to carry out cultural obligations to care for country.

\section{ABORIGINAL KNOWLEDGE, GENOCIDE, ECOCIDE AND RACISM}

In 1999, the UN Special Rapporteur Miguel Martínez identified important work that needed to be done and recommended the inclusion of Indigenous Knowledge in any reading of the status of First Nations treaties negotiated between peoples and states. $^{44}$

Imperial Britain invaded Australia in 1788. After 112 years of bloodshed, the invaded territories were in 1901 re-named the 'Commonwealth of Australia'. This renaming of

39. For further discussion see J Chesterman and B Galligan, Citizens without Rights: Aborigines and Australian Citizenship (Cambridge University Press, Cambridge 1997) 32-3.

40. See Watson, above (n 2), 55-65, 109-43.

41. See Watson, above (n 2), 118-19.

42. C Mattingly and K Hampton, Survival in Our Own Land: 'Aboriginal' Experiences in 'South Australia' since 1836 (Wakefield Press, Adelaide 1988) 48.

43. See Watson, above (n 2), 118-19.

44. Study on Treaties (n 10), para 62. 
First Nations' territories was imposed as though our lands had no pre-existing name or identity of their own. Britain demarcated the six different colonies in Australia by drawing straight lines across our un-ceded territories, ignoring ancient Aboriginal knowledges. Cities and towns - the colonies themselves - were named after colonial identities, while ancient names were banned, to be forgotten. In filling this space, which they perceived as empty, the colonizers acted as if there was no violation of First Nations' laws and sovereignty, and denied their many crimes of genocide. A narrative of peaceful settlement became the dominant account, while invasion, genocide and ecocide are still proscribed terms. ${ }^{45}$ The potential ecocide of our territories continues with each new and damaging development proposal, while First Nations' authority and obligations to care for country are both undermined and limited by the power of the colonial state.

Colonial power was legitimized by the principle of terra nullius, the creation of 'western' lawyers who enacted their contempt for other worlds. The racist construction of Aboriginality which derives from the principle of terra nullius has led to a common 'deficit' characterization and cultural profiling of First Nations Peoples. ${ }^{46}$ The evidence for this can be found in the high levels of incarceration rates of Aboriginal people and other socio-economic deficit victim modelling. ${ }^{47}$ Positive media accounts of Aboriginal Australia are rare, in the face of the 'problem-dysfunction' profile of Aboriginal Peoples.

In Mabo (No 2), Justice Brennan's leading judgment alluded to the problem that the recognition of the crime of genocide could cause for colonial law, as such a recognition would call into question the jurisdiction of the court and the very foundation

45. Australia has the highest rate of mammalian extinction in the world. Over the past 230 years, one in three of Earth's mammal extinctions have occurred in Australia. A 2015 review of the literature indicates that since 1788, 28 species of Australian land mammals have become extinct. This is to be contrasted with post-invasion North America, in which only one mammal species has become extinct in more than 400 years. See J Woinarski, A Burbidge and P Harrison, 'Ongoing Unravelling of a Continental Fauna: Decline and Extinction of Australian Mammals since European Settlement' (2015) 112 Proceedings of the National Academy of Sciences 4531. For information on flora both extinct and threatened, see Department of Environment and Energy, Environment Protection and Biodiversity Conservation Act List of Threatened Flora <http:// www.environment.gov.au/cgi-bin/sprat/public/publicthreatenedlist.pl?wanted=flora $>$ accessed 27 January 2018; and for a comparison with international data on Australia, see 'Fact Check: Does Australia Have One of the "Highest Loss of Species Anywhere in the World?" <http:// www.abc.net.au/news/2015-08-19/fact-check-does-australia-have-one-of-the-highest-extinction/ 6691026> accessed 27 January 2018.

46. Aboriginal communities in the Northern Territory have been represented across Australian media as dysfunctional violent places. In response to violence reported in 2007 the Liberal Howard government announced its intention to use Commonwealth powers to impose a number of 'emergency measures' to control and monitor Aboriginal communities; this response followed the Northern Territory Government, Broad Inquiry into the Protection of Aboriginal Children from Sexual Abuse: Report of the Northern Territory Board of Inquiry into the Protection of Aboriginal Children from Sexual Abuse (2007). To date the violence continues being reported and the characterization of violent Aboriginal communities has stuck.

47. The ABC media response to the Little Children are Sacred Report, the NT intervention, and commonwealth and state policy have characterized the position of Aboriginal Peoples as the 'Aboriginal problem', one to be managed by policies of 'bridging the gap', amongst other responses to groups that are deemed socially disadvantaged; see I Watson, 'In the Northern Territory Intervention, What is Saved or Rescued and at What Cost?' (2009) 15 Cultural Studies Review 45. 
and legitimacy of Australia. ${ }^{48}$ In Re Thompson, Ex parte Nulyarimma and Ors, a First Nation's application to the Australian Capital Territory (ACT) Magistrates Court, argued that recognition of genocide was inevitable if further amendments and limitations made to the Native Title Act 1993 (Cth) were successful. ${ }^{49}$ The application was refused because the court found that the crime of genocide was unknown to the common law of Australia. A further application was then made to the ACT Supreme Court to determine whether the crime of genocide was known to Australian common law. ${ }^{50}$ In spite of the evidence before him demonstrating that genocide had been committed against First Nations Peoples in Australia, Justice Crispin of the Supreme Court of the ACT decided that there was no crime of genocide known to the laws of the ACT. ${ }^{51}$ He concluded:

For present purposes, it is unnecessary for me to determine whether the particular conduct to which he [the Applicant, Kevin Buzzacott] referred would have been sufficient to sustain charges of genocide if such an offence formed part of the domestic law of Australia. There is ample evidence to satisfy me that acts of genocide were committed during the colonization of Australia. ${ }^{52}$

The crime of genocide evolved in international law. In his report to the United Nations, Cobo argued that the practice of states deliberately discriminating against people for their refusal to abandon their culture, customs and traditions could be deemed 'ethnocide' or 'cultural genocide'. ${ }^{53}$ Cobo saw the damage to First Nations lands as being tantamount to ecocide, which, with the consequent ethnocide, would result in a form of genocide. Preventing a group from preserving its traditional forms of life and bringing about the destruction of the culture based upon those forms of life and the disappearance of the group as such, are serious violations of the basic rights and fundamental freedoms of the population in question. ${ }^{54}$

48. Mabo v Queensland (No 2) (1992) 175 CLR 30 (Brennan J ) (High Court of Australia); Antony Anghie refers to terra nullius as a doctrine which jurists and the courts might consider reversing, but they find that they have no choice but to continue to function within the established framework of these doctrines. See Antony Anghie, above (n 6), 112.

49. The Adnyamathanha native title claim was one of the first to be registered in South Australia in March 1999. Within a month of registration - and with that, the 'right' to negotiate - the Australian federal government approved the Beverly Uranium Mine. The mine has been criticized for its use of underground leaching methods in extracting uranium. Agreement was not reached by traditional consensus protocols; only a representation of the Adnyamathanha people agreed to the development of the mine.

50. Re Thompson; ex parte Nulyarimma (1998) 136 ACTR 9 (Supreme Court of the Australian Capital Territory).

51. Ibid, 13 September, paras 69, 72.

52. Ibid para 78. At the time of drafting the UN Convention on Genocide, the Australian government supported the removal of sections concerning cultural genocide. As a result, Australia's oppression of Aboriginal Nations continues unabated and outside international scrutiny. One of many consequences of this is the erosion of Aboriginal languages, which continues to equate to the linguicide of many of them.

53. Hernán Santa Cruz, Special Rapporteur on Racial Discrimination: 'Special Study of Racial Discrimination in the Political, Economic, Social and Cultural Spheres', United Nations Economic and Social Council, E/CN4/Sub 2/307 para 450. Also cited in Martínez Cobo, above (n 15), 16.

54. Martínez Cobo, above (n 15), 17-18. 


\section{ABORIGINAL TITLE}

While Aboriginal title has been criticized for its failure to nullify terra nullius and for its limits in respect of recognition, some First Nations have nevertheless engaged with the process. Often such a decision to engage was made because it was seen as the only option open for First Nations to pursue.

Native title processes are difficult to navigate: the burden of proof rests with the Aboriginal title applicant. Often potential applicants have been unable to prove that they have Aboriginal title over the claimed lands. In Yorta Yorta ${ }^{55}$ the applicants were unsuccessful in proving that they had maintained a continuous connection to their traditional lands and that they continued to hold Aboriginal title. The oral evidence of the Yorta Yorta was trumped by the historic documented evidence of a colonial settler. In 2015, the Australian Law Reform Commission report recommended removing the more technical and complex aspects of proving native title. However, to date there has been no shift in the burden upon Aboriginal Peoples to prove native title. ${ }^{56}$

Native Title negotiations are currently managed pursuant to the Native Title Act, which provides for the negotiation of Indigenous Land Usage Agreements (ILUAs). This is a process that has caused conflict between consenting and non-consenting First Nations Peoples. ${ }^{57}$ One example of conflict concerns the proposed Adani coal mining development in central Queensland. The development has been progressed, in part, through a native title ILUA. ${ }^{58}$ First Nations in conflict over the development have sought a court determination as to the legitimacy of the ILUA agreement. ${ }^{59}$

55. Members of the Yorta Yorta Aboriginal Community v Victoria [1998] 1606 FCA (Olney J), 106, 114, considered and privileged the written evidence of an early colonial settler over that of the contemporary oral history of the Yorta Yorta applicants, in deciding that Aboriginal title had ceased and been 'washed away by the tide of history'. A subsequent appeal to the High Court confirmed Olney J's ruling: Members of the Yorta Yorta Aboriginal Community $v$ Victoria (2002) 214 CLR 422.

56. Australian Law Reform Commission, Review of the Native Title Act (Issues Paper 45, March 2014) <https://www.alrc.gov.au/publications/native-title-ip-45> accessed 20 March 2018.

57. J Robertson, 'Leading Indigenous Lawyer Hits Back at Marcia Langton over Adani', The Guardian (9 June 2017) <https://www.theguardian.com/environment/2017/jun/09/leadingindigenous-lawyer-hits-back-at-marcia-langton-over-adani> accessed 4 August 2017. On the capacity of Australian law to protect country, native title does not provide First Nations with the capacity to care for country in the ways in which we are obliged to, but are rather laws intended to assimilate First Nations into the Australian property law system. Under these laws, land constitutes property, which contradicts our traditional relationships with our territories. See Native Title Act 1993 (Cth); Native Title Amendment Act 1998 (Cth).

58. Indigenous Land Usage Agreements (ILUA) may be negotiated pursuant to the Native Title Act 1993 (Cth), s 24BA. Developments on country are frequently negotiated within an ILUA framework. For example, most large-scale developments, including the Roxby Downs uranium mine, involve an ILUA. Note the confidential character of this agreement: B Fitzgerald and S Martin, '\$900m Olympic Dam Windfall to Indigenous Groups', The Australian (5 May 2012) <http://www.theaustralian.com.au/business/m-olympic-dam-windfall-to-indigenousgroups/story-e6frg8zx-1226347243652> accessed 5 August 2017. The Cameco Corporation uranium mine at Kintyre in the Pilbara region of WA on the lands of the Martu People was also negotiated as an ILUA in 2012: 'Kintyre' (Cameco Australia) <https://www.camecoaustralia. com/projects/kintyre > accessed 5 August 2017.

59. In On 22 June 2017 the Native Title Amendment (Indigenous Land Use Agreements) Act 2017 came into force, amending the Commonwealth Native Title Act 1993. This was to remove 
There are no external or international mechanisms for First Nations Peoples to appeal to, or processes to monitor or intervene in ILUA determinations where Aboriginal Peoples have not agreed to a development which would be destructive to the environment (and which is deemed unlawful from a First Nations' perspective). In 2010 Arabunna elder Kevin Buzzacott spoke about an ILUA which was used to support the proposed expansion of the Roxby Downs copper and uranium mine in South Australia:

We've got Roxby Downs, brothers and sisters and they're talking about a big expansion, like a big open cut mine. It's going to be something like 17, 18 kilometres round and about one mile [deep] in the ground and that's going to be right in the middle. ${ }^{60}$ In the 1980s it was Western Mining Corporation that started off this mine [presently underground]. We didn't want it, we protested it, it's a very sacred place, big stories and now they want to do the expansion and this big open cut mine there. We're worried about that already and they getting the water from the Lake Eyre Basin. They're taking out the water, the sacred water from sacred country again and they're using it, then all our uranium stuff and more sacred water being used. So now with the new railway line [from Adelaide to Darwin] ... they're talking about taking the [uranium] waste all the way up to Muckaty. ${ }^{61}$ Then shipping the uranium out into other countries, and along the way they're going to dump off the waste back in the Muckaty area. Aboriginal peoples living close to this big railway line that they've got now and all the families and people here now are really worried about all that. They're really worried about what's going to happen because again it's a very sacred country. I don't know how they do it; they always want to dig and dump stuff and dig up very sacred places. We want to stop this mob before the bulldozers go in ... because we're born here this old country, our creators created this country for us to look after. Now we're born with the obligations and responsibilities to look after this country. That's what old people say and that's what we've got to do. ${ }^{62}$

The ILUA processes actually enable the development of Aboriginal lands, without requiring a consensus and the free, prior and informed consent of First Nations. ILUA agreements have enabled negotiations which do not acknowledge the authority and protocol of First Nations.

\section{FREE, PRIOR AND INFORMED CONSENT}

The right of self-determination for all peoples is recognized in Article 1 of the two International Covenants on Human Rights. ${ }^{63}$ The right of Indigenous Peoples to self-determination is acknowledged in Article 3 of the United Nations Declaration on

uncertainty around the validity of registered Indigenous Land Use Agreements, following McGlade v Native Title Registrar [2017] FCAFCA 10. The amendment confirms the validity of ILUAs currently on the Native Title Register, and provides validity for those agreements where most of the registered native title applicants have signed.

60. The mine is located at Roxby Downs, approximately $500 \mathrm{~km}$ north of Adelaide, South Australia. The proposal was to turn an existing underground copper, gold and uranium mine into the world's biggest open cut mine.

61. Muckaty is located approximately $120 \mathrm{~km}$ north of Tennant Creek in the Northern Territory.

62. Cited in Watson, above (n 2), 41.

63. International Covenant on Civil and Political Rights, 999 UNTS 171, opened for signature 16 December 1966 (entry into force 23 March 1976) Art 1; International Covenant on Economic, Social and Cultural Rights, UNTS 993, opened for signature 16 December 1966 (entry into force 3 January 1976), Art 1; see also Charter of the United Nations Art 1(2). 
the Rights of Indigenous Peoples (UNDRIP), but it is an underlying right present in almost all other provisions. To recognize the right to self-determination is to accept that as Indigenous Peoples we can and should decide what can take place on our lands. A number of First Nations have accused Australian governments of failing to properly consult with them over development proposals. ${ }^{64}$ Proscribed minimum standards set out in the UNDRIP are often ignored by governments. Historically, First Nations' territories and resources in Australia have been constantly used without our consent. ${ }^{65}$ It should be noted that from an Aboriginal standpoint, consent could not be given to the destruction of our lands, it would be against the laws of First Nations Peoples.

While the colonial state certainly retains military power, the Australian governments have no legitimate authority to grant exploration or development permits. The continued development of our lands without our consent is legitimized by racist ideologies which imply that Aboriginal Peoples have no right to our lands and therefore our consent is not required. No other peoples can have their land staked by mining companies without their consent. That Australia and its constituent states believe they can issue exploration or development permits is a violation of Aboriginal Peoples' territorial integrity and right to say no, even if by their self-styled ILUAs, they have gained 'consent'.

While the UNDRIP is non-binding and cannot enforce its own minimum standards, there nevertheless remains an expectation upon the states and industries involved in the extraction of non-renewable resources that they would comply with the standards set out in it. Article 32(2) requires that states undertake good-faith consultations to obtain free and informed consent to any large-scale projects:

States shall consult and cooperate in good faith with the indigenous peoples concerned through their own representative institutions in order to obtain their free and informed consent prior to the approval of any project affecting their lands or territories and other resources, particularly in connection with the development, utilization or exploitation of mineral, water or other resources.

From the on-going terra nullius standpoint of the state we are deemed to be Peoples with no rights to speak about our territories. However, more importantly, some proposals, for example to frack or develop unconventional gas on our territories, represent such a high risk of damage to our natural environment that we should have a right to veto and to say 'no'. And we do say 'no', but the state retains the power to determine the outcome regardless of First Nations concerns or opposition.

The principle of free prior and informed consent is also referred to in Articles 6 and 15 of International Labour Organization (ILO) Convention 169. Article 6 states that: 'consultations carried out in application of this convention shall be undertaken ... with the objective of achieving agreement or consent to the proposed measures' ${ }^{66}$

64. The Mithaka People made a submission to the UN Special Rapporteur on Indigenous Peoples in 2014, on the failure of the Queensland government to consult in accord with minimum standards of the Declaration, Article 32(2).

65. See Sharon Venne for a discussion of the global impact, S Venne, 'How Governments Manufacture Consent and Use it Against Indigenous Peoples', in Irene Watson (ed), Indigenous Peoples as Subjects of International Law (Routledge, Abingdon 2018) 141.

66. International Labour Organization, Convention Concerning Indigenous and Tribal Peoples in Independent Countries, 76th ILC session, entry into force 5 September 1991, Geneva (adopted 27 June 1989). 
This article can be read alongside Article 15 and in relation to Indigenous Peoples and extractive industries:

In cases in which the State retains the ownership of mineral or sub-surface resources or rights to other resources pertaining to lands, governments shall establish or maintain procedures through which they shall consult these peoples ... before undertaking or permitting any programmes for the exploration or exploitation of such resources pertaining to their lands.

While some states have argued that the principle of consent is absent from the Convention, the ILO's Committee of Experts on the Application of Conventions and Recommendations has on several occasions recalled that, in accordance with Article 6, governments shall consult the peoples concerned with the objective of 'achieving agreement or consent to the proposed measures'. ${ }^{67}$

Further, the Committee on the Elimination of Racial Discrimination (CERD) called upon states parties to 'ensure that members of indigenous peoples have equal rights in respect of effective participation in public life and that no decisions directly relating to their rights and interests are taken without their informed consent' ${ }^{68}$

Free, prior and informed consent has become customary in international law and should be consistently applied to bring a greater balance and place limitations on Australian law regarding the laws of First Nations Peoples. Consultation and the process of free, prior and informed consent, protocols of international law, should be engaged in during any dealings with First Nations Peoples' territories. Nonetheless, according to First Nations law, the destruction of the natural world cannot be consented to; it would be unlawful to do so. First Nations Peoples cannot consent to ecocide in our lands and natural world environment, it would be equivalent to our own genocide. First Nations have the authority to say 'no' to the destruction of our lands and natural world. In Australia, First Nations do not, however, have the power or the mechanisms to support our authority.

\section{FIRST NATIONS CASE STUDIES}

\subsection{Meintangk and Boandik Peoples}

Our nations are concerned about the impact proposed gas-fracking processes would have upon the quality of our air, water and earth-soils in the south-east of South Australia and our food security for the future. Meintangk and Boandik Peoples are concerned that unconventional gas and fracking developments - as has happened in many other areas in Australia and the rest of the world - have the potential to severely damage the environment of our ancient territories and present environmental threats to our lands, waters and our future food security.

However, Meintangk and Boandik Peoples are excluded from decision-making processes which will impact our territories. This is the terra nullius dilemma, namely that Aboriginal Peoples are still deemed inferior to the Euro-origin state and without

67. See for example, Report of the Committee of Experts on the Application of Conventions and Recommendations, Report III(1A), International Labour Conference, Geneva, 2003, cited in United Nations, Department of Economic and Social Affairs, International Workshop on Free, Prior and Informed Consent, New York 17-19 January 2005.

68. Committee on the Elimination of Racial Discrimination, General Recommendation XXIII: Indigenous Peoples, Fifty-First Session, 1997, para 4(d). 
law. Another proposal the Boandik and Meintangk are opposing is the development of a golf course/tourist resort in coastal sand dunes, which if it were to be approved, would threaten ancient camping sites and the burial grounds of ancestors. It will place pressure on the survival of native vegetation and animals, which we call our spirit connection to the natural world - our relations - who, like Aboriginal Peoples are becoming an endangered species. Boandik and Meintangk Peoples have said 'no', but our voices have minimal ranking - mere 'boxes ticked' - in the development schemes supported by the South Australian government. ${ }^{69}$

The ongoing terra nullius approach has been to ignore the Boandik and Meintangk Peoples' sovereignty. In applying its governance, the colonial state has a framework which completely overlooks Aboriginal ontological understandings of the world. Indeed, the conceptualization of nature as a resource for appropriation, economic growth as an endless process for the development of the 'nation state', and accumulation as a natural activity of all human societies are the premises of the state and its resource industries and are in opposition to an Aboriginal ontological way of knowing. ${ }^{70}$

\subsection{Arabunna, Martu Peoples and uranium mining}

The Roxby Downs copper-uranium mine and its processing plant in South Australia were established more than twenty years ago. The mining operations have resulted in the degradation of the local natural environment, the land of the Arabunna People. Forty-five million litres of water per day are being extracted from the Great Artesian Basin around Lake Eyre in Central Australia, in order to process copper and uranium ore. This is dry, vulnerable land, with one of the world's lowest rainfall averages, and the ground water resource is essential for the survival of people and animals in this area. While the state advises that they have obtained consent, Arabunna elder Kevin Buzzacott has protested against the mine since its inception, insisting that from an Arabunna standpoint, consent to the destruction of the land and the unsustainable use of water for minerals processing, could never be given. ${ }^{71}$

A new uranium mine is also being proposed on the lands of the Martu Peoples in Western Australia; the proponent is a Canadian company, Cameco. Although the approvals process is well advanced, many of the Martu First Nation claim that they have not agreed to it. In 2018, the Martu protest continues. ${ }^{72}$

69. This concerns the SA Development Assessment Commission; note that at every level there has been no opportunity to speak about our concerns and no opportunity to appeal the decision of the Minister. Further, there is almost no possibility for judicial review of the final determination, see: <www.sa.gov.au/planning/majordevelopments; https://www.sa.gov. $\mathrm{au} /$ search collection $=$ sagov - web-search $\&$ f.tabs $\% 7 \mathrm{C} 1=$ All \&query $=$ nora + creina + golf + course +and+tourism+resort> accessed 27 January 2018.

70. Irene Watson discusses the capacity for Australian environmental laws to care for country, above (n 38), 209-18. Under the South Australian Aboriginal Heritage Act, s 23, the power to destroy Aboriginal sites is held by the Minister.

71. See Watson (n 2), 46-9.

72. A Sargent, 'Martu People Leave on $110 \mathrm{~km}$ March in Protest Against Pilbara Uranium Mine', ABC News (5 June 2016) <http://www.abc.net.au/news/2016-06-04/martu-people-inthe-pilbara-protest-a-uranium-mine/7476440> accessed 27 January 2018. 


\subsection{Nuclear waste dumps and First Nations}

First Nations have unanimously said 'no' to the development of nuclear waste dumps on their lands in this continent from the mid-1990s onward. During the 1990s and 2000s the Australian federal government proposed the development of a national nuclear waste depository in a region (in South Australia) known as Billa Kallina. ${ }^{73}$ The proposal was for the dump to store the residue of the sole nuclear reactor in Australia, the Lucas Heights machine near Sydney. Currently the waste, generated over the last 60 years, is stored at Lucas Heights. A group of senior Aboriginal women local to Billa Kallina, the Kupa Piti Kungka Tjuta from the Arabunna, Kokatha and Yankuntjatjara Nations said 'no' to this proposal. Due to their sustained opposition, the Billa Kallina site is no longer threatened. However, the federal government followed up with plans to site the nuclear waste dump in the Northern Territory at Muckaty, 120 kilometres north of Tennant Creek. ${ }^{74}$

Agreements over First Nations Peoples' lands in Australia have often involved a small number of individuals agreeing to the proposal and signing-off on it, while the majority continue to oppose it, and the principle of the free, prior and informed consent of the collective is frequently ignored. ${ }^{75}$ Dianne Stokes from Muckaty spoke about her opposition to the federal government's proposed nuclear waste dump being located at Muckaty and the process by which the government purported to have obtained consent. Her opposition highlighted the lack of proper consent being obtained from the peoples who had the authority to speak for the land in question. They had not consented to the nuclear waste dump development. ${ }^{76}$

So, about the waste dump, there wasn't any proper consent and consultation from the traditional owners back home in Tennant Creek when it started off. The first time, I was really happy to follow these Northern Land Council people and the government people, to get my people to say yes, but the waste dump come to the land. And when I think about it in my heart, I shatter sometimes: I shake inside my heart, because I'm feeling it. I know that I would have a bigger problem at the time if I was accepting the waste dump to come to the land. ... I've seen Lucas Heights, ${ }^{77}$ it's got all the drums there all sealed. I went and asked these people at Lucas Heights a question: 'Is it open'? 'No, it's all sealed, it's all

73. Billa Kallina is about $600 \mathrm{~km}$ north-west of Adelaide, South Australia. The Kupa Piti Kungka Tjuta is a group of senior Aboriginal women from the Arabunna, Kokatha, Yankuntjatjara and other peoples based in Coober Pedy, South Australia who were most active against the nuclear waste dump proposal during the 1990s and up until the federal government decision not to site the dump at Billa Kallina. Regarding the proposed Muckaty dump site, see D Sweeney, 'Plan to Use Aboriginal Land as a Nuclear Waste Dump is Flawed and Misguided' The Guardian (London, 31 July 2013).

74. Ibid.

75. Free and prior informed consent 'recognizes indigenous peoples' inherent and prior rights to their lands and resources and respects their legitimate authority to require that third parties enter into an equal and respectful relationship with them, based on the principle of informed consent'. See the UNHCR, Sub-Commission on the Promotion and Protection of Human Rights, Working Group on Indigenous Populations, Twenty-second Session, 19-23 July 2004, 5 .

76. The National Radioactive Management Bill 2010, which among other measures proposed to override Australian Commonwealth and state laws and suspend environmental and Aboriginal heritage protection. It also proposed to exclude the requirement to obtain traditional owners' free, prior and informed consent for any sites being nominated for the nuclear waste dump.

77. A nuclear reactor facility in Sydney, New South Wales. 
tight and won't crash or it won't rust or anything'. But I know drums get rusted; drums do get rusted, because I've seen a lot of these drums rusted along the highway with the tar. That was from before I was born, when they were making the roads going to Queensland. I can see that all along there you've got rusted drums. ... I thought about my grandfather's country, and I say now that I'm not happy with the waste dump coming into the land, because most of my families who fought hard, even my uncle, he was one of them. ... But now he's gone, because he had too much stress - he was worried about the stuff coming into the land. So he said to me, 'I'm going to keep going'. ${ }^{78}$

In the film Muckaty Voices, Barbara Shaw posed a further challenge to the Commonwealth government's selection of the site and to the interpretation of 'free, prior and informed consent' when she referred to Article 29 of the UNDRIP as follows:

Indigenous peoples have the right to the conservation and protection of the environment and the productive capacity of their lands or territories and resources ... [including] no storage or disposal of hazardous materials ... in the lands or territories of indigenous peoples without their free, prior and informed consent. ${ }^{79}$

The Commonwealth withdrew the proposal in the face of these criticisms, and the search for a nuclear waste site continued. And once again, the state has targeted Aboriginal lands for a waste dump. The contemporary target for a new nuclear waste dump is the lands of the Adnyamathanha Peoples. ${ }^{80}$ For now, they have succeeded in stalling the proposal, however, the threat of having a nuclear waste dump foisted upon you remains an ongoing threat to the survival of First Nations and our lands. Elders have many times given government ministers and their bureaucrats warnings about the destruction that these developments would cause to the natural world.

\section{LIVING IN TWO WORLDS}

Aboriginal Peoples live in two worlds, the colonial and the Aboriginal, and many Aboriginal Peoples understand that it is our ancient laws which will ensure the future health of our lands and waters. The maintenance and centring of First Nations' epistemologies is essential to the survival of both peoples and the natural world. However, the dominant narrative is led from a colonialist perspective. It is my view that to understand the Aboriginal world we need to reframe the dialogue. Unless there is a shift in perspective from coloniality we will continue with its progress-development agenda at any cost to our natural world.

Essential to the survival of all species is a horizontal dialogue between colonialist interests and First-Nations-centred epistemologies. Such a dialogue is essential

78. D Stokes, traditional owner, 'Muckaty Community and a Nuclear Waste Dump on our Communal Lands', Presentation at symposium '2007 Declaration on the Rights of Indigenous Peoples: Where to From Here?', David Unaipon College of Indigenous Education and Research, University of South Australia, 10 December 2010.

79. Barbara Shaw speaking with traditional owners in the film Muckaty Voices, produced by Beyond Nuclear Initiative and Enlightening Productions 2010, <www.beyondnuclearinitiative. wordpress.com> accessed 27 January 2018.

80. The Commonwealth Government of Australia has proposed to create a nuclear waste dump in an area which borders the Yappala Indigenous Protected area - in northern South Australia again without the consultation of the Adnyamathanha people. See Norman, above (n 5). 
because currently the fullness of Indigenous epistemologies is ignored and remains largely unfathomable to the non-Indigenous world. The critical need for another way of being law-full is not appreciated, or it is beyond the colonial comprehension. The urgency for all to open their eyes wide and to see and know law beyond the colonialist foundation is critical. The colonial legal system is still sourced in the myths of terra nullius and the fiction that First Nations' laws do not exist. It is this fiction which stands in the way of actually apprehending First Nations law. The colonial project posits and constructs rules which overlay the laws of the land. It rejects First Nations' laws as law, and instead sees them as being no more than oral stories, mere myths and fables. Our laws are dismissed as childlike or primitive, and hence remain unexamined for their ancient coded knowledge of the interdependence between humans and our environments. But many of our stories and songs are now being cited by science (as noted in a recent example concerning the rising waters of the Coral Sea which threaten the Great Barrier Reef, the greatest coral complex on earth). ${ }^{81}$ Science is coming to understand the deeply coded content of Aboriginal songs and stories as a record of the ancient history of life on earth. It has taken a long time for western knowledge systems to engage with and understand First Nations epistemological positions. In my work I have argued for the need for a process of de-coding language and the translation of cultural positions, which could assist in developing deeper engagement and listening to other ways of knowing the world.

Raising similar concerns regarding the position of the colonial and colonized worlds, Boaventura de Sousa Santos advocates action beyond critical discourse and the need for talk about the unspeakable, when he warns of the risk of an epistemicide - the murder of knowledge - occurring if the exclusion of 'different' voices continues to occur. ${ }^{82}$ While I have said above that the law cannot be extinguished, the potential for a juridicide looms if Aboriginal laws continue to be ignored. We might also add that there is the potential for a death of knowledge in terms of First Nations' Peoples as the carriers of law, notwithstanding the fact that the law will go on as it has always done, in its relationship to the natural world. What will change is how knowledge is held by Aboriginal Peoples.

What are the possibilities for a dialogue beyond the dominance of a western-centric universalism and incommensurability between cultures $?^{83}$ Can we imagine an equality of power relations, and shared authority, and the possibility of First Nations' voices being registered, heard and understood from a centred First Nations space? ${ }^{84}$

In order to open up the possibility for a horizontal dialogue, the following questions could lead the process: how do the power relations between First Nations and states translate into Western law? What place or space is there to speak of coloniality, are there spaces that are free of colonialism? Can 'proper' dialogue only flourish where there is a commitment to decolonizing power relations? Can we know and or imagine other ways of being law-full than being within the colonial matrix?

Future possibilities lie in the task before us, that is, to re-centre Aboriginal ways of being. The enabling of a dialogue between states and First Nations should include First Nations' perspectives on authority and power; this should be central to any

81. N Reid and P Nunn, 'Aboriginal Memories of Inundation of the Australian Coast Dating from More than 7000 Years Ago' (2016) 47 Australian Geographer 11.

82. B de Sousa Santos, Epistemologies of the South: Justice Against Epistemicide (Paradigm Publishers, Boulder, CO 2014).

83. Ibid 212 .

84. M Fricker, Epistemic Injustice, Power and the Ethics of Knowing (Oxford University Press, Oxford 2007). 
dialogue, along with the understanding that the natural world holds law and authority. While colonial states are a long way from engagement in such a proposed dialogue, this dialogue could begin between First Nations. This is not a new idea, it is one that is old and ongoing. We need to lift the discourse from its underground existence. The first move is to understand that this process exists, and for First Nations' survival it is essential to enable and maintain the dialogue.

We need to listen to the natural world constantly; now it is changing, howling, raining and drying up. We need to continually monitor dangerous extractive industries which might damage our natural ecosystems. First Nations have never stopped watching and acting; the non-Indigenous world needs to learn how to reciprocate and share the responsibility we have to the natural world. Perhaps it begins with some deep listening to the Indigenous world. The ability to do this is to centre Aboriginality so that it may be seen and heard again. Under the pressure of humanity, our natural world is in crisis and this makes the need to see law truly ever more urgent. ${ }^{85}$ The west has reached the end-point of its progress project, and does not have the solutions to the crisis it has constructed. It has no other lands to invade and colonize beyond leaving our mother Earth and searching for other planets. Current regimes of recognition and protection do not work. We are on the brink of sacrificing our waters, oceans, lands, skies and fellow creatures, which still provide for a planet with too many human beings.

In Australia, the laws said to recognize First Nations come in the form of native title, ${ }^{86}$ Aboriginal Heritage protection ${ }^{87}$ and other-named environmental laws, ${ }^{88}$ and none of them have the capacity to protect the environments which are vital to our survival. We are on a trajectory which, it appears, could sacrifice all life forms. But we still have the capacity for ongoing life. Cycles do return, to begin again. Aboriginal law is an ongoing cycle, law is the law is the law. Within the cycles of law there is the capacity to return to an ongoing cycle of life on Earth. To engage with cyclical thinking would be to re-position linear ideologies that prioritize progress at any cost. Cyclical thinking might just disable the ongoing colonialist progress trajectory which has us set upon a track to global environmental destruction.

\section{CONCLUSION}

There is a debt accruing, a debt that is owed to First Nations and our territories. It is a debt measurable in the displacement of First Nations governance, ${ }^{89}$ a foundational sovereign debt, ${ }^{90}$ that is almost inestimable in dollar terms. In respect of the environment, the damage bill continues to mount. However, the debt owed to First Nations is rarely, if ever, acknowledged or even considered to be one which is owed.

The denial of our rights to our lands and the foundation of the colonial state was and remains based on the racist and unlawful principle of terra nullius. This unlawful

85. de Sousa Santos, above (n 82), 233.

86. Native Title Act 1993 (Cth); Native Title Amendment Act 1998 (Cth).

87. Aboriginal and Torres Strait Islander Heritage Protection Act 1984 (Cth).

88. Environment Protection and Biodiversity Conservation Act 1999 (Cth), among other Australian State and Commonwealth laws.

89. S Motha, 'The Debt Crisis as Crisis of Democracy' (2012) 8 Law, Culture and the Humanities 390.

90. M Giannacopoulos, 'Sovereign Debts: Global Colonialism, Austerity and Neo-Liberal Assimilation' (2015) 19 Law Text Culture 166. 
foundation has resulted in the continual reduction of our Nations' rights to our lands and environments, as well as who we are as Nations of Aboriginal Peoples.

Policies and actions which the Australian government effects in 'our interests', and which are purportedly based on the neoliberal concept of equality, have nothing to do with equality; they are concocted to soothe a collective cognitive and moral dissonance. In fact, at their foundation, all current Australian policies and actions are based on the racist principles of terra nullius and still-current fantasies of racial superiority, and are aimed at extinguishing our identity as Nations of Aboriginal Peoples. Ultimately, these policies and actions still aim to unilaterally absorb us into the grand whiteness of Australia. The continued adherence to terra nullius and current neoliberalism is evidence that the Australian state does not accept us as self-determining Nations of Aboriginal Peoples.

To begin again is a way forward, to ask the Australian State: what underpins your claim to the title to Aboriginal lands? Does Australia renounce terra nullius and the racist principles and beliefs which make up such a doctrine? And, finally, does Australia acknowledge and support all 'Peoples' as having an inherent right to self-determination, and, as a component of such a right, that all 'Peoples' have a right to collectively care for country and to benefit from a relationship to the land which sustains future generations of Peoples? The possibility of a future for all life forms on earth lies in the responses colonial states might deliver to these questions. Returning to and re-empowering Aboriginal authority in relation to the natural world is a way forward; it is an old way, long and tested by time. 